\title{
North American channel catfish, Ictalurus punctatus: a neglected but potentially invasive freshwater fish species?
}

\author{
Phillip J. Haubrock (D) - Gordon H. Copp • Iva Johović • Paride Balzani • \\ Alberto F. Inghilesi · Annamaria Nocita $\cdot$ Elena Tricarico
}

Received: 2 December 2019/ Accepted: 19 January 2021/Published online: 12 February 2021

(C) The Author(s) 2021

\begin{abstract}
The North American channel catfish Ictalurus punctatus has been introduced to several locations in Europe but has received little or no scientific study despite its invasive attributes, including prolific reproduction, tolerance to a wide range of conditions, opportunistic feeding, at least partial 'predator release', and some evidence of environmental impacts (e.g. disease transmission). To assess the species' potential invasiveness and the likely risks to native species and ecosystems in Europe, available
\end{abstract}

Supplementary Information The online version contains supplementary material available at https://doi.org/10.1007/ s10530-021-02459-x.

P. J. Haubrock · A. F. Inghilesi

NEMO, Nature and Environment Management Operators

s.r.1, Viale G. Mazzini 26, 50135 Florence, Italy

\section{P. J. Haubrock}

Faculty of Fisheries and Protection of Waters, University of South Bohemia in České Budějovice, South Bohemian Research Center of Aquaculture and Biodiversity of Hydrocenoses, Zátiší 728/II, 38925 Vodňany, Czech Republic

\section{P. J. Haubrock ( $\square)$}

Department of River Ecology and Conservation, Senckenberg Research Institute and Natural History Museum Frankfurt, 63571 Gelnhausen, Germany e-mail: phillip.haubrock@senckenberg.de

\section{G. H. Copp}

Centre for Environment, Fisheries and Aquaculture

Science, Pakefield Road, Lowestoft NR33 0HT, UK literature from both North America and Europe was reviewed and used to carry out risk screenings of the species for the risk assessment areas, North and South Italy, using the Aquatic Invasiveness Screening Kit (AS-ISK), which was followed by a more detailed evaluation (for both North America and Europe) of the species' potential impacts using the Environmental Impact Classification of Alien Taxa (EICAT) assessment protocol. The AS-ISK score indicated that channel catfish is likely to pose a high risk of being invasive in both North and South Italy, with EICAT scores indicating "Major" impacts for both North America and Europe, at high and medium confidence

\author{
G. H. Copp \\ Centre for Environment and Sustainability, Bournemouth \\ University, Poole, UK \\ G. H. Copp \\ Faculty of Biology and Environmental Protection, \\ University of Łódź, Lodz, Poland \\ G. H. Copp \\ Environmental \& Life Sciences Graduate Programme, \\ Trent University, Ontario K9J 7B8, Canada \\ I. Johović · P. Balzani · A. F. Inghilesi · \\ A. Nocita · E. Tricarico \\ Department of Biology, University of Florence, Via \\ Madonna del Piano 6, 50019 Sesto Fiorentino, \\ FI, Italy
}


levels, respectively. The present results emphasise the urgent need to carry out in-depth studies on introduced populations of this species to understand better its invasive potential so as to inform management decisions on the appropriate control or eradication measures for invaded water bodies.

Keywords Alien species · Invasiveness · Screening · Impact $\cdot$ Management $\cdot$ Assessment

\section{Introduction}

Of the many non-native fish species that have been introduced to the European continent, the North American channel catfish Ictalurus punctatus (Rafinesque, 1818) has received relatively little attention (e.g. Ligas 2007; Haubrock et al. 2018a, b). This contrasts the concerted, comprehensive research on other non-native fishes from North American, such as pumpkinseed Lepomis gibbosus (Copp and Fox 2007; Fox and Copp 2014), black bullhead Ameiurus melas (Copp et al. 2016a) and crucian carp (Tarkan et al. 2016), and from Asia such as the topmouth gudgeon Pseudorasbora parva (Gozlan et al. 2010). This scarcity of scientific study on channel catfish is surprising given its commercial importance to aquaculture and as a sport angling species in both its native and introduced ranges of North America (Brown 1942; Appelget and Smith 1951; Boyd et al. 2000; Rezk et al. 2003; Tucker and Hargreaves 2004; Simmons et al. 2006), as well as in Europe (Carpio et al. 2019). Dedicated studies of channel catfish impacts are limited to the experimental study of Adams (2007), though in a field-based study of non-native fish diet, Poe and Rieman (1988, p. 48) stated that channel catfish "may also be an important predator on juvenile salmonids during the spring in the upper reservoir".

Channel catfish is considered one of the fastest expanding species (Tucker and Hargreaves 2004; Olden and Poff 2005), characterised by attributes suitable for introductions, including high annual survival rates (Blank et al. 2017) and a wide temperature and salinity tolerances $\left(0-38{ }^{\circ} \mathrm{C}\right.$ and $0-11 \mathrm{ppt}$, respectively; Wellborn 1988; see Supplementary Material 1). With an optimum water temperature range between 24 and $30^{\circ} \mathrm{C}$, channel catfish possesses the demonstrated ability to establish self-sustaining populations outside its native range, both when translocated within North America and introduced elsewhere. Vectors for channel catfish introductions and translocations include aquaculture, pet trade and fishery diversification (sometimes referred to as 'enhancement'). The development of channel catfish aquaculture in Europe, e.g. Germany (Hilge 1980), led to the species being introduced to at least 25 countries (Supplementary Material 2), and the species now ranks amongst the top 27 of farmed species (Savini et al. 2010). An early database (Welcomme 1988) suggested that channel catfish had become widespread. As with many non-native species, accurate data on established channel catfish populations are lacking. However, given the species' biology and potential impacts on native species and ecosystems (Haubrock et al. 2018a, b), specific legislation to manage non-native freshwater fishes was enacted in England \& Wales in 1998 (www.legislation.gov.uk/ uksi/1998/2409/made), and ictalurid catfishes were included on the list of non-native species subject to controls for keeping and release (see Table 1 in Copp et al. 2005a). In the EU, channel catfish has been risk assessed with regard to its use in aquaculture (Copp et al. 2016c). Elsewhere, in the absence of similar controls, slow regulatory and management response times can potentially permit the spread through European freshwater ecosystems (Maguire 2004; Crooks 2005), such as was observed with topmouth gudgeon in Europe (Gozlan et al. 2010).

The potential threat of channel catfish to European freshwater ecosystems is especially relevant to southern Europe, and in Italy, which has been reported to have the highest number of introduced fish species (see Table 2 in Copp et al. 2005a; Nocita et al. 2017), channel catfish populations are known to be established in central and northern Italy. This contrasts the distributions throughout Italy of two other North American catfishes, black bullhead Ameiurus melas and brown bullhead Ameiurus nebulosus (Bianco and Ketmaier 2001). The aim of the present study was to evaluate the potential invasiveness of channel catfish in Italy as well as the level of potential adverse impacts in Europe as a whole relative to North America as a whole. In the present article, the term 'invasive' is used according to the definition given in Copp et al. (2005a). The specific objectives were to: (1) review relevant available information on the possible impacts of the species; (2) carry out risk screenings to rank the 
Table 1 Results for channel catfish Ictalurus punctatus of risk screenings using the freshwater Fish Invasiveness Screening Kit (FISK) for risk assessment areas in European countries, with risk scores and outcome classifications of: $\mathrm{M}=$ medium;
$\mathrm{MH}=$ moderately high; $\mathrm{H}=$ high $; \mathrm{VH}=$ very high. Also given are the selection criteria (Crit) used in the cited study and the a priori status (Invasive/Protection), and the associated confidence factor $(\mathrm{CF})$ details

\begin{tabular}{|c|c|c|c|c|c|c|c|c|c|c|c|c|}
\hline \multirow[t]{2}{*}{ Region/country } & \multirow[t]{2}{*}{ Crit } & \multirow[t]{2}{*}{ a priori status } & \multicolumn{4}{|l|}{ Score } & \multirow[t]{2}{*}{ Outcome } & \multicolumn{4}{|l|}{$\mathrm{CF}$} & \multirow[t]{2}{*}{ Refs. } \\
\hline & & & Mean & Min & Max & SE & & Mean & Min & Max & SE & \\
\hline Greece & 2 & $\begin{array}{c}\text { Invasive/not } \\
\text { evaluated }\end{array}$ & 22.3 & 19.0 & 25.5 & 2.7 & MH & 0.83 & 0.80 & 0.86 & 0.03 & $\begin{array}{l}\text { Perdikaris } \\
\text { et al. (2016) }\end{array}$ \\
\hline Bulgaria & na & $\begin{array}{l}\text { Invasive/ } \\
\text { not evaluated }\end{array}$ & 10.0 & & & & $\mathrm{MH}$ & 0.79 & & & & $\begin{array}{l}\text { Simonovic } \\
\text { et al. (2013) }\end{array}$ \\
\hline $\begin{array}{l}\text { England \& } \\
\text { Wales }\end{array}$ & na & $\begin{array}{l}\text { Absent/ } \\
\text { not evaluated }\end{array}$ & 23.8 & & & & $\mathrm{H}$ & & & & & $\begin{array}{l}\text { Copp et al. } \\
(2009 a, b)\end{array}$ \\
\hline $\begin{array}{l}\text { Southern } \\
\text { Finland }\end{array}$ & na & $\begin{array}{l}\text { Invasive/ } \\
\text { not evaluated }\end{array}$ & 11.0 & & & & M & 0.79 & & & & $\begin{array}{l}\text { Puntila et al. } \\
\text { (2013) }\end{array}$ \\
\hline $\begin{array}{l}\text { Iberian } \\
\text { Peninsula }\end{array}$ & 2 & $\begin{array}{l}\text { Invasive/ } \\
\text { not evaluated }\end{array}$ & 31.0 & 26.0 & 38.0 & 3.6 & $\mathrm{VH}$ & 0.81 & 0.71 & 0.96 & 0.08 & $\begin{array}{l}\text { Almeida et al. } \\
\text { (2013) }\end{array}$ \\
\hline $\begin{array}{l}\text { Lake Balaton, } \\
\text { Hungary }\end{array}$ & 2 & $\begin{array}{l}\text { Invasive/least } \\
\text { concern }\end{array}$ & 8.67 & 4.0 & 15.0 & 2.33 & M & 0.78 & 0.8 & 0.9 & 0.26 & $\begin{array}{l}\text { Ferincz et al. } \\
\quad(2016)\end{array}$ \\
\hline North Italy & na & $\begin{array}{l}\text { Invasive/ } \\
\text { not evaluated }\end{array}$ & 31.0 & & & & $\mathrm{H}$ & 0.89 & & & & This study \\
\hline South Italy & na & $\begin{array}{l}\text { Invasive/ } \\
\text { not evaluated }\end{array}$ & 30.0 & & & & $\mathrm{H}$ & 0.92 & & & & This study \\
\hline
\end{tabular}

Table 2 Results for channel catfish Ictalurus punctatus risk screenings made for Turkey using the freshwater Fish Invasiveness Screening Kit (FISK) and the Aquatic Species Invasiveness Screening Kit (AS-ISK) and for Italy using the AS-ISK, including the status criteria $(A Q N=$ Non-native species important for the aquarium trade; NNP = Non-native species already present in the country), the a priori classification (see "Methods"), and the risk screening outcome scores and risk ranks from the Basic Risk Assessment (BRA) and the Climate Change Assessment (CCA). The AS-ISK outcome risk ranks for Turkey are based on the threshold scores (for distinguishing Medium and High risk species) reported in Tarkan et al. (2017) and those used for Italy are given in the "Methods" section

\begin{tabular}{|c|c|c|c|c|c|c|c|c|c|}
\hline \multirow[t]{2}{*}{ Region/country } & \multirow[t]{2}{*}{ Criteria } & \multirow[t]{2}{*}{ a priori status } & \multicolumn{2}{|c|}{ AS-ISK } & \multicolumn{2}{|c|}{ Outcome } & \multicolumn{2}{|l|}{$\mathrm{CF}$} & \multirow[t]{2}{*}{ Refs. } \\
\hline & & & BRA & $\mathrm{BRA}+\mathrm{CCA}$ & FISK & BRA & FISK & BRA CCA & \\
\hline Turkey & AQN & $\begin{array}{l}\text { Invasive/least } \\
\text { concern }\end{array}$ & 31.0 & 41.0 & $\mathrm{H}$ & $\mathrm{H}$ & 0.68 & 0.68 & $\begin{array}{l}\text { Tarkan et al. } \\
\text { (2017) }\end{array}$ \\
\hline North Italy & NNP & Invasive & 44.0 & 54.0 & & & & & This study \\
\hline South Italy & NNP & Not present & 39.5 & 31.5 & & & & & This study \\
\hline
\end{tabular}

species' invasiveness with regard to the northern and southern parts of Italy; and (3) evaluate the potential threats posed by the species for Europe using an impact assessment classification system. Risk analysis of non-native species, which involves risk identification (a.k.a. screening), full risk assessment, risk management and communication, is vital for the protection of European freshwater ecosystems. The outcomes of risk identification and assessments provide the evidence base with which to inform policy makers and environmental managers as to which species are likely to become invasive and exert adverse impacts on native species and ecosystems. This information assists decision makers in identifying where management resources can be most effectively deployed to eradicate or control invasive species.

\section{Methods}

Literature searches were undertaken via www.google. com and www.google.scholar.com using a variety of 
search terms (invasive, alien, non-native, impact, aquaculture, disease, pathogens, control, management) in combination with the species' common and scientific names. A total of 512 articles were retrieved, and of these, those containing valuable and for this study relevant information on this species' invasiveness were retained. Also, online databases (www. fishbase.org, Froese and Pauly 2010; www.cabi.org, CABI 2016; www.gbif.org, gbif.org 2020; all accessed: 15.01.2021) and grey literature were consulted. Lastly, various ichthyologists, zoologists and experts from several European countries were consulted on their knowledge of channel catfish introductions in their respective countries. Grey literature on channel catfish was limited (e.g. Poe and Rieman 1988; Jackson and Badame 2002), so only peer-reviewed literature sources were ranked according to the number of references sourced and their reliability as: 'low' (one reference), 'medium' (multiple references or single plus personal reference) and 'high' (multiple recent references). The same bibliographic search strategy and sources were used to answer questions in the risk screening and impact assessments described here below. Conversions factors for fish lengths (fork and standard) into total length (TL) were taken from www. fishbase.org, whereby conversions of standard length to TL employed the mean (1.2605) of the two values given on FishBase.

Consistent with the stepwise risk analysis process (see Introduction), the species was evaluated in a twostep process: risk screening, followed by detailed impact assessment. Risk screening of the species was undertaken using the Aquatic Species Invasiveness Screening Kit (AS-ISK; Copp et al. 2016b), which: (i) complies with the with the 'minimum standards' (Roy et al. 2018) for the assessment of NN species under EC Regulation No. 1143/2014 on the prevention and management of the introduction and spread of invasive alien species (the IAS Regulation) (Council of the European Communities 2014); and (ii) offers assessors 32 languages with which to carry out their assessments (Copp et al. 2021). As with its parent screening tools, the Weed Risk Assessment (Pheloung et al. 1999) and the Fish Invasiveness Screening Kit (Copp et al. 2009b; Vilizzi et al. 2019), the AS-ISK comprises 49 basic (BRA) questions to evaluate a species' biogeography/history, biology/ecology, and nuisance traits, followed by six additional Climate Change Assessment (CCA) questions, which require the assessor to estimate how the future climatic conditions are likely to affect the risks of introduction, dispersal, establishment and impacts of the assessed species (Copp et al. 2016b). For each question, the assessor must provide a response and a justification (i.e. bibliographic support) for that response, and also to rank their level of confidence in that response. As recommended by the Intergovernmental Panel on Climate Change (IPCC 2005; e.g. Copp et al. 2009b), the confidence factor $(\mathrm{CF})$ rankings are: Low (2 out of 10 chance); Medium ( 5 out of 10 chance); High ( 8 out of 10 chance); Very high ( 9 out of 10 chance).

Using the AS-ISK's German-language option, but providing justifications in English, the risk screenings were carried out separately for the north and northeast of Italy (henceforth, North Italy) and south and southwest of Italy (henceforth, South Italy), i.e. the two risk assessment (RA) areas because of their different climate types, according to Köppen-Geiger (Beck et al. 2018), and different freshwater ecoregions (Abell et al. 2008). The Köppen-Geiger climate types are $\mathrm{Cfb}$ (temperate oceanic climate) and $\mathrm{Csa} / \mathrm{Csb}$ (hotsummer Mediterranean climate) for North and South Italy, which both possess similarities with the species' native range (Beck et al. 2018). The freshwater ecoregion 415 (Gulf of Venice Drainages) (Abell et al. 2008) corresponds to the North Italy RA area, and ecoregion 416 (Italian Peninsula and Islands) corresponds to the South Italy RA area (Supplementary Material 3). The distinction of different freshwater ecoregions within a country in risk screenings has been found to be important to ensure the most accurate evaluation of potential risk, especially within an environmental management context (Dodd et al. 2019).

In the absence of a calibrated AS-ISK threshold score for non-native freshwater fishes with which to distinguish between high and medium-to-low risk species in Italy (sensu Copp et al. 2009b), the global threshold scores acquired for temperate zone freshwater fishes in a global trial of the AS-ISK (L. Vilizzi, G.H. Copp et al. unpublished) were used (i.e. BRA = 15.9; $\mathrm{BRA}+\mathrm{CCA}=16.0$ ). This global trial study includes AS-ISK assessments of channel catfish for several RA areas (Belarus, Southern Finland, Turkey, Vietnam, Anzali Wetland Complex-Iran, River $\mathrm{Ob}$ Basin-Russia) as well as the two assessments for north and south Italy. 
Following the risk screening, the species was subjected to a more comprehensive assessment of the magnitude of channel catfish adverse impacts in the RA area using the Environmental Impact Classification of Alien Taxa (EICAT) of Blackburn et al. (2011), which was applied with regard to the species' introduced ranges in North America and in Europe. Based on the generic impact scoring system (GISS) of Nentwig et al. (2010, 2015), the EICAT was modified to align it to the IUCN's impact scheme (Kumschick et al. 2012) and has recently been announced (IUCN 2020) as the IUCN's standard for the classification of non-native species impacts on the environment (www. iucn.org/theme/species/our-work/invasive-species/ eicat). The system ranks the magnitude of species environmental impacts using five semi-quantitative scenarios, ranging from Minimal (species is unlikely to cause deleterious impacts on the native biota or abiotic environment) to Massive (species is likely to lead to the replacement and local extinction of native species, and to produce irreversible changes in the structure of communities and the abiotic or biotic composition of ecosystems). A species' environmental impacts are measured using 12 classes of impact mechanism, each associated with one of a sequential series of five impact scenarios, which describe the increasing magnitude of the species' impact. For each impact mechanism in EICAT, a confidence level is also allocated: high, medium, and low (Blackburn et al. 2011). Species are assigned to an impact category based of the largest impact value recorded, whereas the overall confidence is taken from the impact category attributed the highest confidence rank (Blackburn et al. 2011).

\section{Results}

The AS-ISK assessments of channel catfish resulted in high scores and corresponding high-risk classification for both North and South Italy (Table 1; see also Supplementary Material 4), though the scores for North Italy (BRA $=44.0)$ were higher than those for South Italy $(B R A=36.5)$. These differences were attributable to the sections A2 (Climate, distribution and introduction risk) and A3 (Invasive elsewhere). The likely impact of climate change on the screenings also differed between the north, where invasiveness risk increased $(\mathrm{BRA}+\mathrm{CCA}=54.0)$ in contrast to a decrease in the south (BRA $+\mathrm{CCA}=28.5)$. Assessor confidence was relatively high for both North and South with regard to the BRA (CFs $=0.80$ and 0.92 , respectively), but with regard to climate-change impacts on likely invasiveness (BRA + CCA) confidence dropped less for the North $(\mathrm{CF}=0.54)$ than for the South $(\mathrm{CF}=0.25)$. These differences could be attributed to the sections A2 (Climate, distribution and introduction risk), A3 (Invasive elsewhere) and C9 (Climate change).

The EICAT impact assessments revealed that the species can be classified as exerting "Major impacts" in both North America and Europe, with confidence levels of "low" and "medium" for North America and Europe, respectively (Table 3). With both the AS-ISK and EICAT evaluations, the scarcity of information on the risks and impacts of introduced populations was a major contributor to the confidence rankings.

\section{Discussion}

Information available in the literature on channel catfish was mainly on the species' environmental biology in its native, North American range, with limited information from Europe and elsewhere. Following the species' first introduction to Europe in the 19th century for angling and aquaculture, it has been recorded in at least 22 EU-countries, being considered as established in nine (Welcomme 1988; Elvira and Almodóvar 2001; Copp et al. 2005a; Olenin et al. 2008, CABI 2016; Supplementary material 2; Fig. 1) with recent information on its potential impact reported in Italy (Haubrock et al. 2018a, b).

There have been few studies to examine the appropriate spatial scale for risk assessments: national, regional, legislatively defined (e.g. River Basin District) or climo-geographic (Dodd et al. 2019). This is relevant to both non-native and translocated species, with differing climates within a region (present study) or River Basin District (Dodd et al. 2019). Differences in climate suitability have implications for the success of invasive species. Especially temperature regimes affect e.g. the success of spawning. Although the Köppen-Geiger climate in South Italy (Csb/a, at least one month's average temperature above $22{ }^{\circ} \mathrm{C}$ ) is characterised by a hotter summer than North Italy (Cfb; with all months with average temperatures below $22{ }^{\circ} \mathrm{C}$ ) and therefore comparable to $I$. 
Table 3 Outcomes of the environmental impact classification of Alien Taxa (EICAT; Blackburn et al. 2011) applied to the channel catfish Ictalurus punctatus in the introduced range in North America and Europe

\begin{tabular}{|c|c|c|c|c|c|c|}
\hline \multicolumn{4}{|l|}{ North America } & \multicolumn{3}{|l|}{ Europe } \\
\hline $\begin{array}{l}\text { Ecological } \\
\text { impacts }\end{array}$ & Impact & Uncertainty & Explanation & Impact & Uncertainty & Explanation \\
\hline Competition & 4 & 1 & $\begin{array}{l}\text { Competition for food, site } \\
\text { for reproduction } \\
\text { showed in field and } \\
\text { laboratory experiments }\end{array}$ & 3 & 3 & $\begin{array}{l}\text { No data of competition with } \\
\text { native species. It can only be } \\
\text { hypothesized from data }\end{array}$ \\
\hline Predation & 4 & 1 & $\begin{array}{l}\text { Stomach content analyses } \\
\text { and laboratory } \\
\text { experiments with } \\
\text { different prey items }\end{array}$ & 4 & 2 & $\begin{array}{l}\text { Stomach content analysis } \\
\text { revealed high predation and } \\
\text { opportunistic behaviour }\end{array}$ \\
\hline Hybridisation & 4 & 1 & $\begin{array}{l}\text { It can hybridize with } \\
\text { other native Ictaluridae }\end{array}$ & 1 & 2 & No hybridization reported \\
\hline $\begin{array}{l}\text { Transmission } \\
\text { diseases to } \\
\text { native }\end{array}$ & 1 & 3 & No data reported & 1 & 2 & $\begin{array}{l}\text { No documented diseases } \\
\text { transmitted to native species, } \\
\text { but possibly to Silurus glanis }\end{array}$ \\
\hline Parasitism & 1 & 3 & $\begin{array}{l}\text { Nematodes are reported } \\
\text { in the species but } \\
\text { transmission to other } \\
\text { species has not been } \\
\text { documented so far }\end{array}$ & 1 & 3 & No impacts reported \\
\hline Poisoning/toxicity & 1 & 1 & $\begin{array}{l}\text { Spines are toxic and a } \\
\text { defence mechanism, but } \\
\text { no data on heavy effects } \\
\text { on native species }\end{array}$ & 1 & 2 & $\begin{array}{l}\text { Spines are toxic and a defence } \\
\text { mechanism, but no data on } \\
\text { heavy effects on native } \\
\text { species }\end{array}$ \\
\hline Bio-fouling & 1 & 1 & No impacts reported & 1 & 1 & No impacts reported \\
\hline Herbivory & 3 & 2 & $\begin{array}{l}\text { It is opportunistic and can } \\
\text { eat algae and small } \\
\text { aquatic plants }\end{array}$ & 3 & 2 & $\begin{array}{l}\text { It is opportunistic and can eat } \\
\text { algae and small aquatic } \\
\text { plants. }\end{array}$ \\
\hline $\begin{array}{l}\text { Physical, } \\
\text { chemical, } \\
\text { structural }\end{array}$ & 1 & 2 & No impacts reported & 2 & 3 & Only hypothesis \\
\hline Interaction & 1 & 3 & No data reported & 2 & 3 & $\begin{array}{l}\text { It can transmit diseases to } \\
\text { other alien fishes, it can } \\
\text { predate American crayfish; } \\
\text { it can hybridize with other } \\
\text { alien Ictaluridae }\end{array}$ \\
\hline Final score & 4 & & & Final score & 4 & \\
\hline Category & Major & MU) & & Category & $\begin{array}{l}\text { Major } \\
\text { (MU) }\end{array}$ & \\
\hline $\begin{array}{l}\text { Level of } \\
\text { confidence }\end{array}$ & 3 (High & & & $\begin{array}{l}\text { Level of } \\
\text { confidence }\end{array}$ & 2 (Medium) & \\
\hline
\end{tabular}

punctatus' native range, both North Italy and South Italy are likely to provide sufficient summer temperatures required for successful spawning and successive development (Appelget and Smith 1951; Wellborn 1988).
Indeed, while the climate zone in the species' native area North America is characterised by at least one month's mean temperature $>22^{\circ} \mathrm{C}$, future temperature increases under recently modelled climate change scenarios (Solomon 2007; Collins et al. 2013) will likely facilitate dispersal and establishment of channel 


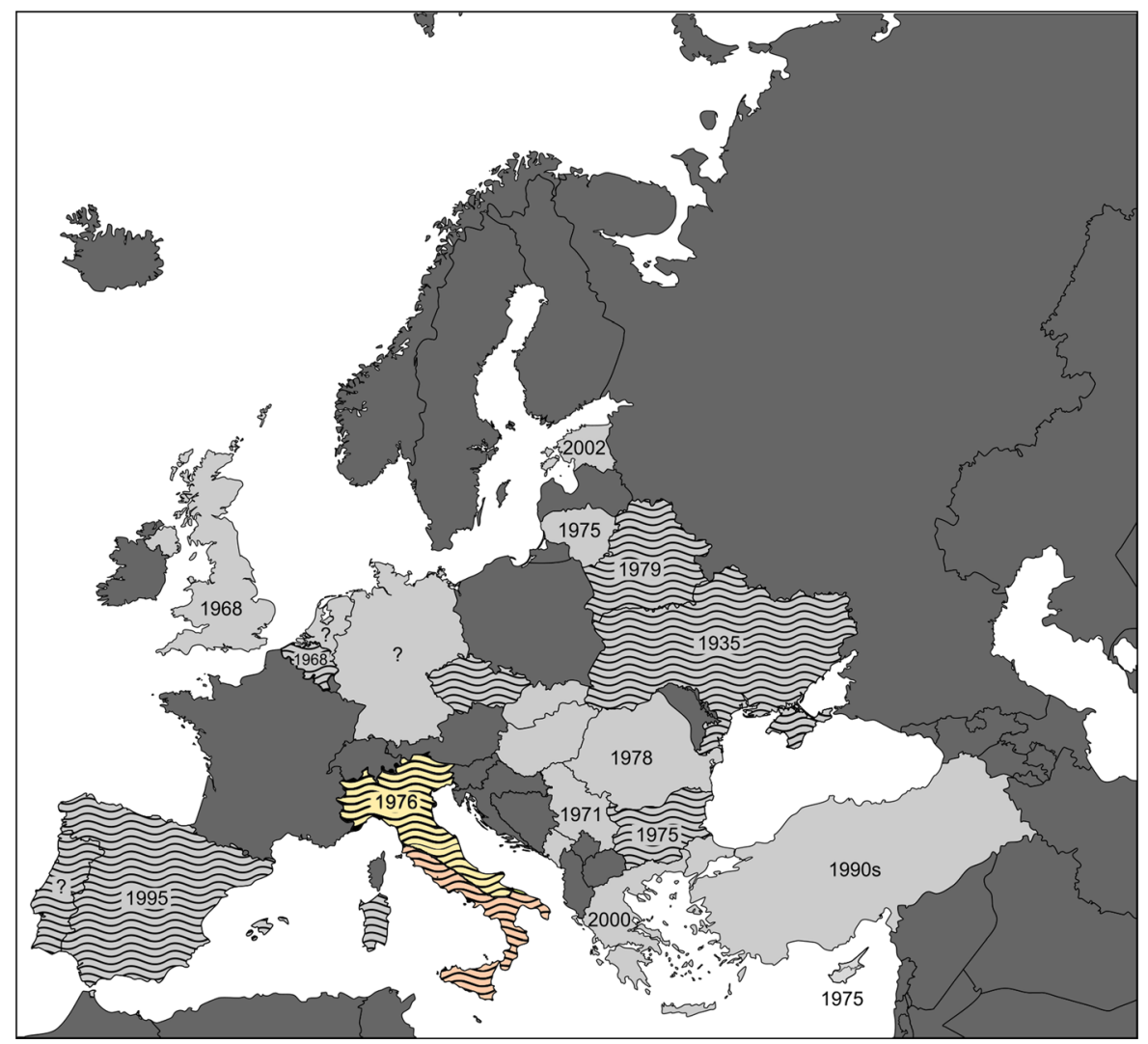

Fig. 1 Map of Europe indicating countries (light grey) and the year when the channel catfish Ictalurus punctatus was introduced. Countries where evidence exists for the establishment of

catfish in North Italy, including areas of higher altitude. A similar increased distribution may also occur in South Italy, though dry summers with low precipitation will likely render some locations unsuitable. However, previous risk screenings of channel catfish for several European Countries (Greece, Bulgaria, Finland and the Iberian Peninsula) using the precursor to the AS-ISK, freshwater Fish Invasiveness Screening Kit (FISK), resulted in medium and high risk classifications-this includes Turkey for which the species was screening using both the FISK and the AS-ISK (Table 2), with the lowest risk rankings (and low scores) being for Lake Balaton (Hungary) and for southern Finland. When considering the potential impact for the European continent as indicated by EICAT, a "major impact with medium uncertainties", corroborates the FISK and AS-ISK scores (Tables 1 and 2).

The combinations of risk screening and impact assessment for the two RA areas revealed several populations in the wild are highlighted with dashed lines. For Italy, the climatic zones of the temperate north and continental south are indicated

unstudied aspects of channel catfish environmental biology, especially pertaining to the species' invasiveness. These gaps in knowledge become more prominent when focused on populations in Europe, as only a handful studies focused on the invasiveness and impacts of this species (see Haubrock et al. 2018a, b). Nonetheless, data on translocated populations in North America revealed that channel catfish were considered invasive where introduced, attracting the highest invasiveness ranking (based on 'expert opinion') for the Colorado River Basin (Hawkins and Nesler 1991), with potential impacts on endangered species, fisheries and angling. The invasiveness potential of channel catfish is enhanced by its migratory behaviour, i.e. to spawning and feeding habitats in spring and autumn, respectively (Duncan and Myers 1978; Becker 1983; Dames et al. 1989; Hanzawa and Arayama 2007). The species' moderately broad temperature requirement $\left(16-24{ }^{\circ} \mathrm{C}\right)$ to induce spawning activity (Appelget and Smith 1951) would also 
facilitate establishment in various climatic regions globally. Similar to many invasive freshwater fishes, the channel catfish is an opportunistic, omnivorous forager, and like other ictalurid catfishes, it possesses venomous dorsal and pectoral spines, which can dissuade some predators (Supplementary Material 1). However, genetic differences between native and introduced populations can lead to variations in the expression of biological traits (Gozlan et al. 2020), which may introduce errors in the interpretation of native-range data in risk assessments-a methodological issue that demands further investigation.

Furthermore, the distribution data revealed that much information on the species' establishment success is purely anecdotal, resulting in low confidence levels. That said, the Mediterranean distribution of channel catfish is most likely linked to angling (Banha et al. 2017), a known vector for the introduction and secondary spread on non-native fishes (e.g. Copp et al. 2005b; Kilian et al. 2012; Anderson et al. 2014). Whereas most channel catfish populations in Eastern Europe can be linked to aquaculture escapes (Savini et al. 2010), such as during natural flood or spate events (Robinette and Knight 1981; Townsend and Winterbourn 1992; Orsi and Agostinho 1999; Zanata et al. 2016). Moreover, its invasiveness is bolstered in some countries, where it is popular among anglers, and also because it can be easily reared in aquaculture. Based on information from the species' introduced North American range, and the likelihood of accidental escapes, the proposed introduction of channel catfish to New Zealand was denied due to the high risk posed by the species to native species of conservation concern (Townsend and Winterbourn 1992).

Recorded impact mechanisms are manifold and include: (i) predation; (ii) competition; (iii) hybridisation with congeneric catfishes (Goudie et al. 1994; Dunham and Masser 2012), though none of these are present in Italy (Movchan et al. 2014); (iv) disease transmission, and (v) modification of ecosystem services and related socio-economic impacts (see Supplementary Material 4). Among the impact mechanisms the species could exert in Europe, and especially Italy, include predation on benthic species, insects, plants and macroinvertebrates, which could reduce native biodiversity. Particularly, with the high densities tending towards young age groups, behavioural interferences as well as competition for food and shelter may result in decreasing abundances of native fish (Jenkins and Burkhead 1994). However, beside native fishes, other several already endangered species may be threatened by its presence due to its opportunistic feeding activity (Endo et al. 2015; Haubrock et al. 2018a, b; 2020).

Studies of introduced pumpkinseed L. gibbosus have shown that, according to life-history traits (mortality rate, plasticity and reproductive strategy), maturity is reached earlier in Europe (Cucherousset et al. 2009). In channel catfish, which mature generally at ages 5-8 years in Canada (Scott and Crossman 1973) and 2.0-5.6 years in the southern U.S.A. (e.g. Perry and Carver 1972), though ages at maturity of $<2$ years and 9 years have been reported (Bates et al. 2001; Shephard and Jackson 2005), spawning can be inhibited if suitable nesting cover is unavailable (Marzolf 1957). Furthermore, climatic differences can affect growth, spawning, and metabolism and eventually lead to precocious maturity and further unforeseeable changes in behavioural patterns altering its invasiveness (Wellborn 1988). For instance, pumpkinseed cease feeding activity at temperatures below $8.5^{\circ} \mathrm{C}$ (Keast 1968). Needing higher temperatures for feeding ( $>15.5^{\circ} \mathrm{C}$, Brown 1942), channel catfish growth rate has been found to increase with increasing population density (Shephard and Jackson 2009), and growth phases are limited to temperatures $>18{ }^{\circ} \mathrm{C}$ (Starostka and Nelson 1974). Indeed, elevated water temperature can lead to faster growth, such as observed in a cooling-water reservoir in Bulgaria, where channel catfish reached TLs at age 2 Bulgaria of $59.2 \mathrm{~cm}$ TL (Hubenova et al. 2014); this is about twice that $(26.9 \mathrm{~mm}$ TL) reported in Scott and Crossman (1973) for age-2 fish in the Upper Mississippi (Iowa) and far exceeds the TLs at age 2 reported in for channel catfish in various lakes (10.8-20.4 cm TL; Starostka and Nelson 1974) and rivers (11.4-19.3 cm TL; Shephard and Jackson 2006) in the U.S.A.

In both North and South Italy (see Methods), the growth season is from June to September (i.e. mean temperatures $>18{ }^{\circ} \mathrm{C}$; World Meteorological Organization 2011). This indicates that channel catfish should be able to undertake growth throughout Italy, but reproduction may be expected to be limited to waters in which mean temperatures reach 23.9-29.5 ${ }^{\circ} \mathrm{C}$ (Scott and Crossman 1973).

Similar to other (non-native) ictalurid catfish population in Europe, the channel catfish has a limited 
number of natural predators, which include pikeperches Sander spp. (Scott and Crossman 1973; Hanchin et al. 2002), cormorants Phalacrocorax spp., herons Ardea spp., pelicans Pelecanus spp. and otters (Lutra lutra). Younger (smaller) channel catfish are particularly susceptible to avian predators (Glahn and Dorr 2002; Wywialowski 1999). However, despite its strongly piscivorous diet, the northern pike Esox lucius is not likely to take ictalurid catfishes. Experimental studies revealed that all sizes of northern pike avoided black bullhead offered as prey (Mauck and Coble 1971) and field studies of northern pike and walleye Sander vitreum diet found channel catfish to be taken by walleye but not northern pike (Tyus and Beard 1990). This information from the native range suggests that the main potential predators of channel catfish in Europe are otters, herons and cormorants, pikeperches and European catfish Silurus glanis (Copp et al. 2009a).

Nevertheless, potential predation by native or nonnative species has yet not been assessed, though diet analysis of European catfish has found this species to predate small $(<80 \mathrm{~cm} \mathrm{TL})$, immature individuals of channel catfish (Haubrock et al. 2019) and black bullhead of 105-200 mm TL (Pouyet 1987; see also Copp et al. 2009a). Angling of channel catfish is lower in Italy than in the native region (Leonard et al. 2010), suggesting that little if any human pressure is exerted on this species. However, human alteration of the environment has long been reported to facilitate species invasions (Moyle 1986; Havel et al. 2005; Olden and Poff 2005; Cucherousset et al. 2009, 2012).

A very well-known example of another North American catfish invader in Europe, including in Italy, is the black bullhead, which first appeared in the United Kingdom in 1885 (Wheeler 1978), reaching Italy in 1904 (Tortonese 1970). The key drivers for non-native fish introductions have often been cultural, because the stocking of exotic species is often perceived as favourable and beneficial for local municipalities and their fisheries (Selge et al. 2011; Kilian et al. 2012). These are seen as enhancements of fish stocks for recreational angling and/or aquaculture. As a result, the black bullhead has already spread throughout Italy, reaching high densities in the River Tiber and the Corbara Reservoir (Pedicillo et al. 2008). Currently, black bullhead is considered established in both North and South Italy, though populations are more common and more abundant in the north of Italy, contrasting the South, where black bullhead populations are limited to reservoirs and other drought-resistant water bodies (Nocita and Zerunian 2007; Marrone and Naselli-Flores 2015). Although black bullhead generally prefers a temperate/mesothermal climate (REF), which contrasts the tropical to mega-thermal climate preferred by channel catfish (Cheetham et al. 1976), climatic conditions may not be limiting factors for either species in Italy, but climatic conditions may be the underlying differences in the establishment success and expansion across Europe, such as reported for European catfish. Another North American catfish present in Europe is the brown bullhead, which was found in a recent full risk assessment (for the EU as the RA area) to pose a medium risk at a moderate confidence level (Aislabie et al. 2019). Unlike the black bullhead, the brown bullhead has received limited study in Europe until recently (Kozic and Vilizzi 2021).

In conclusion, most of the information on the impacts of channel catfish is available for the species' introduced range in North America, whereas for Europe, data are scarce (Supplementary Material 1 and 4). Risk screenings and assessments of the channel catfish have resulted in risk rankings of medium to high risk (Table 2; Supplementary Material 4), and assessment of environmental and economic impacts using the GISS resulted in a medium risk score (Van der Veer and Nentwig 2015). This contrasts the moderately-low risk ranking attributed to channel catfish using the Organism module of the ENSARS, the European Non-native Species in Aquaculture Risk Assessment Scheme (Copp et al. 2016c), though the ENSARS scoring system has yet to be calibrated. These outcomes, combined with the assessments presented here, highlight the urgent need of more research on the species in Europe in order to better investigate its potential invasiveness and promote adequate management plans. Nevertheless, the channel catfish can be considered as potentially invasive fish species in many parts of Europe, though this comes with a caveat for low certainty due to the scarcity of data on European populations and any realised impacts. Information regarding impacts were inferred from literature related to North American invaded areas and, for some impact mechanisms (e.g. predation), from direct observations (Haubrock et al. 2018b, 2019). The high physiological tolerance and fecundity accompanied by parental care make this 
species a good candidate for future successful invasions throughout European water bodies (Marchetti et al. 2004). By natural or human mediated spread, urban areas with rivers already disturbed and invaded by other species are prone to introductions and subsequently facilitate its population growth. With only limited scientific attention being paid to the spread of this potentially invasive species, there are risks of at least moderate-to-major impacts to European freshwater ecosystems. In view of the presence of channel catfish in fresh waters of more than 20 European countries, the potential impacts of this species require urgent study so as to inform risk analysis of this species. Given that the AS-ISK is compliant with the 'minimum standards' for assessing risks under the EU IAS Regulation on (European Union 2014), the high-risk ranking found in the present risk screening suggests this species be subject to regulation under that piece of legislation. The core of the IAS Regulation is the list of Invasive Alien Species of Union concern, which is being updated as appropriate (first update on 2.08. 2017, second update 15.08.2019.) and currently third update is in process of finalisation that took into consideration two ictalurid species, Ameirus melas and Ameirus nebulosus. Species on the list are subject to the restrictions on keeping, importing, selling, breeding and growing and Member States are required to manage these species.

Control or eradication methods do currently exist for ictalurid catfishes (e.g. Copp et al. 2016a; Aldridge et al. 2019), though unlike the UK, use of rotenone elsewhere in Europe may not be possible.

Acknowledgements We thank K. Magellan for helpful comments on an earlier version of the manuscript and T. Jüza, K. Jakubčinová, R. Striekworld, E. Uzunova, J. Cucherousset, G. Hotos, T. Friendrich and F. Ribeiro for information on the introduction history of channel catfish. This project has received funding from the European Union's Horizon 2020 research and innovation programme under the project Marie SkłodowskaCurie Aquainvad-ED (H2020-MSCA-ITN-2014-ETN-642197). The participation of G.H. Copp was supported by Cefas' Science Excellence fund.

Funding Open Access funding enabled and organized by Projekt DEAL.

Open Access This article is licensed under a Creative Commons Attribution 4.0 International License, which permits use, sharing, adaptation, distribution and reproduction in any medium or format, as long as you give appropriate credit to the original author(s) and the source, provide a link to the Creative
Commons licence, and indicate if changes were made. The images or other third party material in this article are included in the article's Creative Commons licence, unless indicated otherwise in a credit line to the material. If material is not included in the article's Creative Commons licence and your intended use is not permitted by statutory regulation or exceeds the permitted use, you will need to obtain permission directly from the copyright holder. To view a copy of this licence, visit http://creativecommons.org/licenses/by/4.0/.

\section{References}

Abell R, Thieme ML, Revenga C, Bryer M, Kottelat M, Bogutskaya N, Stiassny ML (2008) Freshwater ecoregions of the world: a new map of biogeographic units for freshwater biodiversity conservation. AIBS Bull 58(5):403-414

Adams SB (2007) Direct and indirect effects of channel catfish (Ictalurus punctatus) on native crayfishes (Cambaridae) in experimental tanks. Am Midl Nat 158:85-96

Aislabie LR, Verreycken H, Copp GH (2019) Study on Invasive Alien Species-development of risk assessments to tackle priority species and enhance prevention. Contract No 07.0202/2016/740982/ETU/ENV.D2. Final Report, Annex 3: Risk Assessment for Ameiurus nebulosus (Lesueur, 1819). https://doi.org/10.13140/RG.2.2.24531.81444

Aldridge D, Ockendon N, Rocha R, Smith RK, Sutherland WJ (2019) Some aspects of control of freshwater invasive species. In: WJ Sutherland LV, Dicks N, Ockendon SO, Petrova RK, Smith (eds) What Works in Conservation 2019. Open Book Publishers, Cambridge, pp 569-602

Anderson LG, White PC, Stebbing PD, Stentiford GD, Dunn AM (2014) Biosecurity and vector behaviour: evaluating the potential threat posed by anglers and canoeists as pathways for the spread of invasive non-native species and pathogens. PLoS ONE 9:e92788

Appelget J, Smith LL (1951) The determination of age and rate of growth from vertebrae of the channel catfish, Ictalurus lacustris punctatus. Trans Am Fish Soc 80:119-139

Banha F, Veríssimo A, Ribeiro F, Anastácio PM (2017) Forensic reconstruction of Ictalurus punctatus invasion routes using on-line fishermen records. Knowl Manag Aquat Ecosyst 418:56

Bates MC, Tiersch TR, Zhang Q, McElroy MG (2001) A precocious population of channel catfish with potential as a research model. Proc Ann Conf Southeast Assoc Fish Wild! Agencies 55:223-234

Beck HE, Zimmermann NE, McVicar TR, Vergopolan N, Berg A, Wood EF (2018) Present and future Köppen-Geiger climate classification maps at $1-\mathrm{km}$ resolution. Sci Data $5: 1-12$

Becker GC (1983) Fishes of Wisconsin, vol 12. University of Wisconsin Press, Madison

Bianco PG, Ketmaier V (2001) Anthropogenic changes in the freshwater fish fauna of Italy, with reference to the central region and Barbus graellsii, a newly established alien species of Iberian origin. J Fish Biol 59:190-208 
Blackburn TM, Pyšek P, Bacher S, Carlton JT, Duncan RP, Jarošík V, Richardson D (2011) A proposed unified framework for biological invasions. TREE 26:333-339

Blank AJ, Hamel MJ, Spurgeon JJ, Pegg MA (2017) Assessment of a channel catfish population in a large open river system. Fish Manag Ecol 24:460-468

Boyd CE, Queiroz J, Lee J, Rowan M, Whitis GN, Gross A (2000) Environmental assessment of channel catfish Ictalurus punctatus farming in Alabama. J World Aquac Soc 31:511-544

Brown L (1942) Propagation of the spotted channel catfish (Ictalurus lacustrus punctatus). Trans Kansas Acad Sci 45:311-314

CABI (2016) www.cabi.org/isc/datasheet/79127. Accessed 1 Dec 2016

Carpio AJ, De Miguel RJ, Oteros J, Hillström L, Tortosa FS (2019) Angling as a source of non-native freshwater fish: a European review. Biol Invasions 21:3233-3248

Cheetham JL, Garten CL, King CL, Smith MH (1976) Temperature tolerance and preference of immature channel catfish (Ictalurus punctatus). Copeia 1976(3):609-612

Collins M, Knutti R, Arblaster J, Dufresne JL, Fichefet T, Friedlingstein P, Shongwe M (2013) Long-term climate change: projections, commitments and irreversibility. In Climate Change 2013-The Physical Science Basis: Contribution of Working Group I to the Fifth Assessment Report of the Intergovernmental Panel on Climate Change: 1029-1136. Cambridge University Press

Compendium IS Ameiurus melas (black bullhead). www.cabi. org/isc/datasheet/94466 Accessed 27.11.2020

Copp GH, Bianco PG, Bogutskaya NG, Erős T, Falka I, Ferreira MT, Fox MG, Freyhof J, Gozlan RE, Grabowska J, Kováč V, Moreno-Amich R, Naseka AM, Peňàz M, Povž M, Przybylski M, Robillard M, Russell IC, Stakenas S, Šumer S, Vila-Gispert A, Wiesner C (2005a) To be, or not to be, a non-native freshwater fish? J Appl Ichthyol 21:242-262

Copp GH, Wesley KJ, Vilizzi L (2005b) Pathways of ornamental and aquarium fish introductions into urban ponds of Epping Forest (London, England): the human vector. J Appl Ichthyol 21:263-274

Copp GH, Fox MG (2007) Growth and life history traits of introduced pumpkinseed (Lepomis gibbosus) in Europe, and the relevance to invasiveness potential. In: Gherardi F (ed) Freshwater bioinvaders: profiles, distribution, and threats. Springer, Berlin, pp 289-306

Copp GH, Robert Britton J, Cucherousset J, García-Berthou E, Kirk R, Peeler E, Stakènas S (2009a) Voracious invader or benign feline? A review of the environmental biology of European catfish Silurus glanis in its native and introduced ranges. Fish Fish 10:252-282

Copp GH, Vilizzi L, Mumford J, Fenwick GV, Godard MJ, Gozlan RE (2009b) Calibration of FISK, an invasiveness screening tool for nonnative freshwater fishes. Risk Analy 29:457-467

Copp GH, Tarkan AS, Masson G, Godard MJ, Koščo J, Kováč V, Novomeská A, Miranda R, Cucherousset J, Pedicillo G, Blackwell BG (2016) A review of growth and life-history traits of native and non-native European populations of black bullhead Ameiurus melas. Rev Fish Biol Fish 26:441-469
Copp GH, Vilizzi L, Tidbury H, Stebbing PD, Trakan AS, Miossec L, Goulletquer P (2016b) Development of a generic decision-support tool for identifying potentially invasive aquatic taxa: AS-ISK. Manag Biol Invasions $7: 343-350$

Copp GH, Godard MJ, Russell IC, Peeler EJ, Gherardi F, Tricarico E, Miossec L, Goulletquer P, Almeida D, Britton JR, Vilizzi L (2016c) A preliminary evaluation of the European Non-native Species in Aquaculture Risk Assessment Scheme applied to species listed on Annex IV of the EU Alien Species Regulation. Fish Manag Ecol 23:12-20

Copp GH, Vilizzi L, Wei H, Li S, Piria M, Al-Faisal AJ, Almeida D, Atique U, Al-Wazzan Z, Bakiu R, Bašić T, Bui TD, Castro N, Canning-Clode J, Chaichana R, Çoker T, Dashinov D, Ekmekçi FG, Erős T, Ferincz Á, Ferreira MT, Giannetto D, Gilles AS Jr, Głowacki Ł, Goulletquer P, Interesova E, Iqbal S, Jakubčinová K, Kanongdate K, Kim J-E, Kopecký O, Kostov V, Koutsikos N, Kozic S, Kristan P, Kurita Y, Lee H-G, Leuven RSEW, Li S, Lipinskaya T, Lukas J, Marchini A, González Martínez AI, Masson L, Memedemin D, Moghaddas SD, Monteiro J, Mumladze L, Naddafi R, Năvodaru I, Olsson KH, Onikura N, Paganelli D, Pavia RT Jr, Perdikaris C, Pickholz R, Povž M, Preda C, Ristovska M, Rosíková K, Santos JM, Semenchenko V, Senanan W, Simonović P, Smeti E, Števove B, Švolíková K, Ta KA, Tarkan AS, Top N, Tricarico E, Uzunova E, Vardakas L, Verreyken H, Zięba G, Mendoza R (2021) Speaking their language-development of a multi-lingual decision-support tool for communicating invasive species risks to decision makers and stakeholders. Environ Model Softw 135:104900

Cucherousset J, Copp GH, Fox MG, Sterud E, Van Kleef HH, Verreycken H, Záhorská E (2009) Life-history traits and potential invasiveness of introduced pumpkinseed Lepomis gibbosus populations in northwestern Europe. Biol Invasions 11:2171-2180

Cucherousset J, Boulêtreau S, Martino A, Roussel JM, Santoul F (2012) Using stable isotope analyses to determine the ecological effects of non-native fishes. Fish Manag Ecol 19:111-119

Crooks JA (2005) Lag times and exotic species: the ecology and management of biological invasions in slow-motion. Ecoscience 12:316-329

Dames HR, Coon TG, Robinson JW (1989) Movements of the channel and flathead catfishes between the Missouri River and a tributary, Perche Creek. Trans Am Fish Soc 118:670-679

Dodd JA, Vilizzi L, Bean CW, Davison PI, Copp GH (2019) At what spatial scale should risk screenings of translocated freshwater fishes be undertaken-river basin district or climo-geographic designation? Biol Conserv 230:122-130

Dunham RA, Masser MP (2012) Production of hybrid catfish

Duncan TO, Myers MR (1978) Movements of channel and flathead catfish in Beaver Reservoir, Northwest Arkansas. Proc Arkansas Acad Sci 32:43-45

Elvira B, Almodóvar A (2001) Freshwater fish introductions in Spain: facts and figures at the beginning of the 21 st century. J Fish Biol 59(Suppl A):323-331

Endo T, Kaneko S, Igari K, Kanou K, Nakazato R, Kamei R, Usui S, Hyakunari W (2015) Feeding characteristics of the channel catfish Ictalurus punctatus in the littoral zone on 
Lake Kitaura, Ibaraki Prefecture, Japan. Aquac Sci 63:49-58

European Union (2014) Regulation (EU) No 1143/2014 of the European Parliament and of the Council of 22 October 2014 on the prevention and management of the introduction and spread of invasive alien species. OJ 57:35

Ferincz Á, Staszny Á, Weiperth A, Takács P, Urbányi B, Vilizzi L, Paulovits G, Copp GH (2016) Risk assessment of nonnative fishes in the catchment of the largest Central-European shallow lake (Lake Balaton, Hungary). Hydrobiologia 780:85-97

Fox MG, Copp GH (2014) Old world versus new world: lifehistory alterations in a successful invader introduced across Europe. Oecologia 174(2):435-446

Froese R, Pauly D (2010) www.FishBase.org. Accessed 02.11 .2027

GBIF.org (2020) GBIF Home Page. www.gbif.org [13 January 2020]

Glahn JF, Dorr BS (2002) Captive double-crested cormorant Phalacrocorax auritus predation on channel catfish Ictalurus punctatus fingerlings and its influence on singlebatch cropping production. J World Aquac Soc 33:85-93

Goudie CA, Tiersch TR, Simco BA, Davis KB, Liu Q (1994) Early growth and morphology among hybrids of ictalurid catfishes. J Appl Aquac 3:235-256

Gozlan RE, Andreou D, Asaeda T, Beyer K, Bouhadad R, Burnard D, Caiola N, Cakic P, Djikanovic V, Esmaeili HR, Falka I, Golicher D, Harka A, Jeney G, Kováč V, Musil J, Nocita A, Povž M, Poulet N, Virbickas T, Wolter C, Tarkan AS, Tricarico E, Trichkova T, Verreycken H, Witkowski A, Zhang C, Zweimueller I, Britton JR (2010) Pan-continental invasion of Pseudorasbora parva: towards a better understanding of freshwater fish invasions. Fish Fish 11:315-340

Gozlan RE, Záhorská E, Cherif E, Asaeda T, Britton JR, Chang CH, Hong T, Miranda R, Musil J, Povž M, Tarkan AS (2020) Native drivers of fish life history traits are lost during the invasion process. Ecol Evol 10:8623-8633

Hanchin PA, Willis DW, Hubers MJ (2002) Black bullhead growth in South Dakota waters: limnological and community influences. J Freshw Ecol 17(1):65-73

Hanzawa H, Arayama K (2007) Seasonal distribution patterns of the alien species, the channel catfish, Ictalurus punctatus, in Lake Kaumigaura, Ibaraki Prefecture, Japan. Aquac Sci 55:515-520

Haubrock PJ, Azzini M, Fribbi I, Inghilesi AF, Tricarico E (2018) Opportunistic alien catfish: unexpected findings in the diet of the alien species Ictalurus punctatus in Central Italy. Fish Aquat Life 26:239-242

Haubrock PJ, Balzani P, Johovic I, Inghilesi AF, Nocita A, Tricarico E (2018b) The diet of the alien channel catfish Ictalurus punctatus in the River Arno (Central Italy). Aquat Invas 13:575-585

Haubrock PJ, Azzini M, Balzani P, Inghilesi AF, Tricarico E (2020) When alien catfish meet-resource overlap between the North American Ictalurus punctatus and immature European Silurus glanis in the Arno River (Italy). Ecol Freshw Fish 29:4-17

Haubrock PJ, Balzani P, Azzini M, Inghilesi AF, Veselý L, Guo W, Tricarico E (2019) Shared histories of co-evolution may affect trophic interactions in a freshwater community dominated by alien species. Front Ecol Evol 7:355

Havel JE, Lee CE, Vander Zanden JM (2005) Do reservoirs facilitate invasions into landscapes? BioScience 55:518-525

Hawkins JA, Nesler TP (1991) Nonnative fishes of the upper Colorado River basin: an issue paper. Report to the Upper Colorado River Endangered Fish Recovery Program, US Fish \& Wildlife Service, Lakewood, Colorado. Larval Fish Laboratory contribution 48, Colorado State University, Fort Collins. (https://warnercnr.colostate.edu/wp-content/ uploads/sites/2/2017/04/LFL-048-Hawkins_and_Nesler1991-Pub.pdf)

Hilge V (1980) Experiments made with the culture of the channel catfish (Ictalurus punctatus) in Germany. In: Experiences with new native and non-native species in aquaculture of the Federal Republic of Germany. Arb Dtsch Fisch-Verb, vol 30, pp 99-104 (in German)

Hubenova T, Iliev I, Zaikov A (2014) Reproductive biology of the channel catfish (Ictalurus punctatus Raf.) reared in heated water. Bulg J Agric Sci 20:957-961

IPCC (2005) Guidance Notes for Lead Authors of the IPCC Fourth Assessment Report on Addressing Uncertainties. Intergovernmental Panel on Climate Change, WMO \& UNEP. www.ipcc.ch/pdf/assessment-report/ar4/wg1/ar4uncertaintyguidancenote.pdf. Accessed 26 Sept 2018

IUCN (2020) Standard to support global action on invasive alien species. https://www.iucn.org/news/species/202009/iucnstandard-support-global-action-invasive-alien-species

Jackson JA, Badame PV (2002) Centrarchid and channel catfish control in the middle and lower Green River; 1997 and 1998. Upper Colorado River Endangered Fish Recovery Program Project 59. Utah Division of Wildlife Resources, Utah, USA

Jenkins RE, Burkhead NM (1994) Freshwater fishes of Virginia. American Fisheries Society, Bethesda

Keast A (1968) Feeding of some Great Lakes fishes at low temperatures. J Fish Res Board Canada 25:1199-1218

Kilian JV, Klauda RJ, Widman S, Kashiwagi M, Bourquin R, Weglein S, Schuster J (2012) An assessment of a bait industry and angler behavior as a vector of invasive species. Biol Invasions 14:1469-1481

Kozic S, Vilizzi L (2021) Growth, reproduction and trophic ecology of the non-native ictalurid catfish brown bullhead Ameiurus nebulosus in Polish waters. Project description www.researchgate.net/project/Growth-reproduction-andtrophic-ecology-of-the-non-native-ictalurid-catfishbrown-bullhead-Ameiurus-nebulosus-in-Polish-waters. Accessed 15 Jan 2021

Kumschick S, Bacher S, Dawson W, Heikkilä J, Sendek A, Pluess T (2012) A conceptual framework for prioritization of invasive alien species for management according to their impact. NeoBiota 15:69-100

Leonard DM, DeVries DR, Wright RA (2010) Investigating interactions between channel catfish and other sport fishes in small impoundments. N Am J Fish Manag 30:732-741

Ligas A (2007) Population dynamics of the channel catfish, Ictalurus punctatus (Rafinesque 1818), in the Ombrone River (Tuscany, Italy). Atti Soc Toscana Sci Nat Mem Ser B 114:57-62 
Maguire LA (2004) What can decision analysis do for invasive species management? Risk Anal 24:859-868

Marchetti MP, Moyle PB, Levine R (2004) Invasive species profiling? Exploring the characteristics of non-native fishes across invasion stages in California. Freshw Biol 49:646-661

Marrone F, Naselli-Flores L (2015) A review on the animal xenodiversity in Sicilian inland waters (Italy). Advances in Oceanography and Limnology

Marzolf RC (1957) The reproduction of channel catfish in Missouri ponds. J Wildl Manag 21:22-28

Mauck WL, Coble DW (1971) Vulnerability of some fishes to northern pike (Esox lucius) predation. J Fish Res Board Can 28:957-969

Movchan YV, Talabishka EM, Velikopolskiy IJ (2014) Fishes of the genus Ameiurus (Ictaluridae, Siluriformes) in the transcarpathian water bodies. Vest Zool 48:149-156

Moyle PB (1986) Fish introductions into North America: patterns and ecological impact. In: Mooney HA, Drake JA (eds) Ecology of Biological Invasion of North America and Hawaii. Ecological Studies 58. Springer, New York, pp 27-43

Nentwig W, Kühnel E, Bacher S (2010) A generic impact scoring system applied to alien mammals in Europe. Conserv Biol 24:302-311

Nentwig W, Bacher S, Pyšek P, Vilà M, Kumschick S (2015) The generic impact scoring system (GISS): a standardized tool to quantify the impacts of alien species. Environ Monit Assess 188:315

Nocita A, Zerunian S (2007) L'ittiofauna aliena nei fiumi e nei laghi d'Italia. Biol Ambientale 21:93-96

Nocita A, Tricarico E, Bertolino S (2017) Fine-scale analysis of heavily invaded Italian freshwater fish assemblages. Integr Zool 12:500-511

Olden JD, Poff NL (2005) Long-term trends of native and nonnative fish faunas in the American Southwest. Anim Biodivers Conserv 28(1):75-89

Olenin S, Didžiulis V, Ovcarenko I, Olenin I, Nunn AD, Cowx IG (2008) Environmental impacts of alien species in aquaculture. Sustainable management of Europe's natural resources. D1.4 Review of introduction of aquatic species in Europe. IMPASSE Project No 044142

Orsi ML, Agostinho AA (1999) Introducao de especies de peixes por escapes acidentais de tanques de cultivo em rios da bacia do Rio Parana, Brasil. Rev Brasil Zool 16:557-560

Pedicillo G, Bicchi A, Angeli V, Carosi A, Viali P, Lorenzoni M (2008) Growth of black bullhead Ameiurus melas (Rafinesque, 1820) in Corbara Reservoir (Umbria-Italy). Knowl Manag Aquat Ecosyst 389:05

Perdikaris C, Koutsikos N, Vardakas L, Kommatas D, Simonović P, Paschos I, Copp GH (2016) Risk screening of nonnative, translocated and traded aquarium freshwater fishes in Greece using Fish Invasiveness Screening Kit. Fish Manag Ecol 23:32-43

Perry WG Jr, Carver DC (1972) Length at maturity and total length-collarbone length conversions for channel catfish, Ictalurus punctatus, and blue catfish, Ictalurus furcatus, collected from the marshes of southwest Louisiana. Proc Ann Conf Southeast Assoc Fish Wild! Agencies 26:541-553
Pheloung PC, Williams PA, Halloy SR (1999) A weed risk assessment model for use as a biosecurity tool evaluating plant introductions. J Environ Manag 57:239-251

Poe TP, Rieman BE (1988) Predation by resident fish on juvenile salmonids in John Day Reservoir, 1983-1986. Final Report of Research (DE-AI79-82BP34796 and DEAI79-82BP35079) Bonneville Power Administration

Pouyet C (1987) Étude des relations trophiques entre poissons carnassiers dans une rivière de seconde catégorie, référence particulière au silure glane (Silurus glanis, Siluridae) Rapport technique de DEA. Université de Lyon I, France, $25 \mathrm{p}$

Puntila R, Vilizzi L, Lehtiniemi M, Copp GH (2013) First application of FISK, the freshwater fish invasiveness screening kit, in northern Europe: example of southern Finland. Risk Anal 33:1397-1403

Rezk MA, Smitherman RO, Williams JC, Nichols A, Kucuktas H, Dunham RA (2003) Response to three generations of selection for increased body weight in channel catfish, Ictalurus punctatus, grown in earthen ponds. Aquaculture 228:69-79

Robinette HR, Knight SS (1981) Foods of channel catfish during flooding of the Tombigbee River, Mississippi. Proc Southeast Assoc Fish Wildl Agencies 35:598-606

Roy HE, Rabitsch W, Scalera R, Stewart A, Gallardo B, Genovesi P, Essl F, Adriaens T, Bacher S, Booy O, Branquart E, Brunel S, Copp GH, Dean H, D'hondt B, Josefsson M, Kenis M, Kettunen M, Linnamagi M, Lucy F, Martinou A, Moore N, Nentwig W, Nieto A, Pergl J, Peyton J, Roques A, Schindler S, Schönrogge K, Solarz W, Stebbing PD, Trichkova T, Vanderhoeven S, Van Valkenburg J, Zenetos A (2018) Developing a framework of minimum standards for the risk assessment of alien species. J Appl Ecol 55:526-538

Savini D, Occhipinti-Ambrogi A, Marchini A, Tricarico E, Gherardi F, Olenin S, Gollasch S (2010) The top 27 animal alien species introduced into Europe for aquaculture and related activities. J Appl Ichthyol 26:1-7

Selge S, Fischer A, Van der Wal R (2011) Public and professional views on invasive alien species-A qualitative social scientific investigation. Biol Cons 144:3089-3097

Scott WB, Crossman EJ (1973) Freshwater Fishes of Canada. Bulletin 184. Fisheries Research Board of Canada, Ottawa

Shephard S, Jackson DC (2005) Channel catfish maturation in Mississippi streams. North Am J Fish Manag 25:1467-1475

Shephard S, Jackson DC (2006) Difference in channel catfish growth among Mississippi stream basins. Trans Am Fish Soc 135:1224-1229

Shephard S, Jackson DC (2009) Density-independent growth of floodplain river channel catfish Ictalurus punctatus. J Fish Biol 74:2409-2414

Simmons M, Mickett K, Kucuktas H, Li P, Dunhan RA, Liu Z (2006) Comparison of domestic and wild channel catfish (Ictalurus punctatus) populations provides no evidence for genetic impact. Aquaculture 252:133-146

Simonović P, Tošić A, Vassilev M, Apostolou A, Mrdak D, Ristovska M, Copp GH (2013) Risk assessment of nonnative fishes in the Balkans Region using FISK, the invasiveness screening tool for non-native freshwater fishes. Mediterr Mar Sci 14:369-376 
Smith NW (1974) Age, growth, food, fecundity, maturation and local distribution of channel catfish (Ictalurus punctatus) in the Ottawa River near Ottawa and Hull, Canada. MSc Thesis. University of Ottawa, Ottawa, Canada

Solomon S (2007) IPCC 2007: Climate change the physical science basis. AGUFM 2007 (2007): U43D-01

Starostka VJ, Nelson WR (1974) Age, growth, sexual maturity, and food of channel catfish in central Lake Oahe, 1968-69. Technical Paper 81 of the U.S. Fish and Wildlife Service, Washington, DC

Tarkan AS, Almeida D, Godard MJ, Gaygusuz Ö, Rylands MS, Sayer CD, Zięba G, Copp GH (2016) A review and metaanalysis of growth and life-history traits of a declining European freshwater fish, crucian carp Carassius carassius. Aquat Conserv Mar Freshw Ecosyst 26:212-224

Tarkan AS, Vilizzi L, Top N, Ekmekçi FG, Stebbing PD, Copp $\mathrm{GH}$ (2017) Identification of potentially invasive freshwater fishes, including translocated species, in Turkey using the Aquatic Species Invasiveness Screening Kit (AS-ISK). Intern Rev Hydrobiol 102:47-56

Tortonese E (1970) Osteichthyes (Pesci Ossei) I, Fauna Ittica 10

Townsend CR, Winterbourn MJ (1992) Assessment of the environmental risk posed by an exotic fish-the proposed introduction of channel catfish (Ictalurus punctatus) to New Zealand. Conserv Biol 6:273-282

Tucker CS, Hargreaves JA (2004) Biology and culture of channel catfish. Elsevier, Amsterdam

Tyus HM, Beard JM (1990) Esox lucius (Esocidae) and Stizostedion vitreum (Percidae) in the Green River basin, Colorado and Utah. Gt Basin Nat 50:33-39
Van der Veer G, Nentwig W (2015) Environmental and economic impact assessment of alien and invasive fish species in Europe using the generic impact scoring system. Ecol Freshw Fish 24:646-656

Vilizzi L, Copp GH, Adamovich B, Almeida D, Chan J, Davison PI, Zeng Y (2019) A global review and meta-analysis of applications of the Fish Invasiveness Screening Kit. Rev Fish Biol Fish 29:529-568

Welcomme RL (1988) International introductions of inland aquatic species. FAO Fisheries Technical Paper 294: 318 $\mathrm{pp}$

Wellborn TL (1988) Channel catfish: life history and biology. Southern Regional Aquaculture Center Publication No. 180. Southern Regional Aquaculture Center, Texas Agricultural Extension Service, College Station, Texas, USA

Wywialowski AP (1999) Wildlife-caused losses for producers of channel catfish Ictalurus punctatus in 1996. J World Aquac Soc 30(4):461-472

Zanata AS, Ramos IP, DaSilva RJ, Langeani F, Carvalho ED (2016) Pisces, Siluriformes, Ictaluridae, Ictalurus punctatus (Rafinesque 1818): first record in middle Paranapanema river reservoir, aquaculture and exotic species dispersion. Check List 6:589-591

Publisher's note Springer Nature remains neutral with regard to jurisdictional claims in published maps and institutional affiliations. 